UNIO - EU Law Jounal. Vol. 2, No. 2, June 2016, pp 71-81.

®2016 Centre of Studies in European Union Law

School of Law - University of Minho

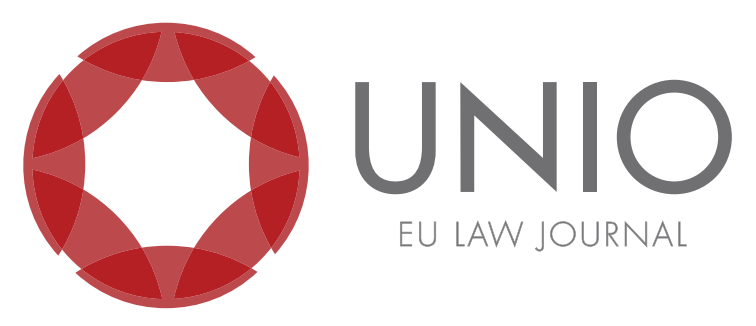

\title{
The European recognition of professional qualifications - a legal framework for the European citizenship
}

\section{Raquel Torres*}

ABSTR ACT: Thispaper discusses the evolution of the requirements for recognition of professional qualifications within the European project. In order to do this, an explanation will, first, be given of the first legal measures and the subsequent period of transformation, which led to the legal framework that is in place today. Following this, a brief comment will be given on other political and legal movements that favored the implementation of the recognition systems in the European context, namely the Bologna and Copenhagen Processes that instigated a strong cooperation to achieve European common standards for the Member States' educational systems. Finally, this legal evolution will inform this paper's considerations of the implications this evolution will have on the construction of a European citizenship.

KEYWORDS: European Law - recognition - professional qualifications - mobility - single market.

\footnotetext{
* Master in European Perspectives on Social Inclusion and Collaborating Member of Manuel Firmino $\&$ Associados, Lda. - Consultancy, research and intervention.

The author would like to recognize and thank the support and encouragement received from Professor Alessandra Silveira in the development of this paper.
} 


\section{From equivalence to recognition}

Since recognition usually happens "when moving across borders," it is clear that this concept, within the European legal framework, has a long lasting and complex history, in parallel with that of Europe's integration and its succeeding unification. As Rauhvargers announces, "over the last 20 years the overall concept of recognition has changed substantially," and it's those changes that this paper will address with the purpose of (re)conceptualize the meaning of recognition of professional qualifications in the context of the European project.

As a result of an integration policy, the united Europe project has had since its origins, a strong commitment to upholding the principle of the free movement of people, especially for, inter alia, fostering collaboration aimed at economic purposes. Indeed, already in 1957, the Treaty of $\mathrm{Rome}^{3}$ created the European Economic Community (henceforth, EEC) and, subsequently, the Common Market (henceforth, CM) (1958). This European drive was justified by the necessity of economic cooperation in behalf of global interchange and competitiveness, which was favorably accepted by the population, and instigated "the 'European fact' in and outside the Community" . Within those concerns, that Treaty implemented, among others, the freedom of movement of workers (Article 48), the freedom to provide services (Article 59) and the freedom of establishment (Article 52) that implied, namely in the latter, to "issue directives for the mutual recognition of diplomas, certificates and other evidence of formal qualifications" (Article 57), which nowadays are represented in the Treaty on the functioning of the European Union (also known as Treaty of Lisbon, implemented in 2007) ${ }^{5}$ as Articles 45, 56, 49 and 53 respectively.

In fact, it quickly became clear that the creation of regulations on the recognition of professional qualifications was essential in fulfilling these liberties and promote the common market. In this sense, the first European Directive on recognition of qualifications appeared in 1959 - the European Convention on the Academic Recognition of University Qualifications - proclaiming that Member States; "shall grant academic recognition to university qualifications conferred by a university situated in the territory of another Contracting Party." However, within this period there were already implemented two other legal texts - the European Convention on the Equivalence of Diplomas leading to Admission in Universities $(1953)^{8}$ and the European Convention on the Equivalence of

\footnotetext{
${ }^{1}$ Andrejs Rauhvargers, "Recognition of foreign qualifications: a guidebook", paper presented at the Official Bologna process conference - improving the recognition system of degrees and study credit points in the European Higher Education Area, University of Latvia, Riga, Latvia, December 3-4, 2004, available online at http://www.aic.lv/rigaseminar/documents/broch spec.pdf.

2 Andrejs Rauhvargers, "Recognition and qualifications frameworks", in Assessment in Education: Principles, Policy \& Practice, 16:1, 2009, 111, DOI: 10.1080/09695940802704161.

3 Treaty establishing the European Economic Community (TEEC) signed on 25 March 1957, founding a regional organization aimed at economic cooperation.

${ }^{4}$ João M. Campos and João L. Campos, Manual de Direito Europeu, Coimbra: Coimbra Editora, 2010, 54.

${ }^{5}$ Treaty on the Functioning of the European Union (TFEU), that amended the Treaty on European Union and the Treaty Establishing the European Community, signed on 13 December 2007, OJ C 326, 26.10.2012, 47-390.

${ }^{6}$ Council of Europe Convention of 14 December 1959 on the Academic Recognition of University Qualifications, European Treaty Series - No. 32.

${ }^{7}$ See Article 3.

${ }^{8}$ Council of Europe Convention of 11 December 1953 on the Equivalence of Diplomas leading to Admission in Universities European Treaty Series - No. 15, and its Protocol of 3 June 1964 to the European Convention on the Equivalence of Diplomas leading to Admission in Universities,
} 
Periods of University Study (1956) ${ }^{9}$ - with the objective of enhancing comparability of access and frequency of university degrees. Consequently, although the European Convention of university qualifications referred to the recognition, in practice the ideology that prevailed was that of equivalence based on a complete matching process, undertaken by academic institutions, between the structures of their courses.

The UNESCO Convention on the Recognition of Studies, Diplomas and Degrees concerning Higher Education in the States belonging to the Europe Region was adopted in Paris in 21 December 1979. ${ }^{10}$ Article 1 of the aforementioned Convention states that "the "recognition" of a foreign certificate, diploma or degree of higher education means its acceptance as a valid credential by the competent authorities in a Contracting State and the granting to its holder of rights enjoyed by persons who possess a national certificate, diploma or degree with which the foreign one is assessed as comparable." Hence, it's important to be noticed that this legal text promotes an understanding of recognition as acceptance, dodging the equivalence paradigm.

Within this scenario, the concept of recognition was re-taken by European institutions only in 1984 with the creation of the National Academic Recognition Information Centers network (hereinafter, NARIC) by the European Commission. These centers were disseminated by all Member States, with the core objective of simplifying academic recognition between them by providing information and assistance in mobility situations. Moreover, some specific professions such as; nurse responsible for general care, dental practitioner, veterinary surgeon, midwife, architect, pharmacist and doctor, started to acquired mutual recognition Europewide over the harmonization of a set of minimum training conditions. ${ }^{11}$

Also, the Council of Europe (henceforth, CoE) introduced a general system for the recognition of higher education diplomas awarded on the completion of professional education and training of at least three years' duration ${ }^{12}$ which provided a set of rules and procedures for recognition of unregulated and regulated professions/professional activities. Likewise, this Directive distinguished regulated profession as the range of regulated professional activities understood "as the taking up or pursuit of such activity or one of its modes of pursuit in a Member State is subject, directly or indirectly by virtue of laws, regulations or administrative provisions, to the possession of a diploma." "13 Finally, a European Convention on the General Equivalence of Periods

European Treaty Series - No. 49.

${ }^{9}$ Council of Europe Convention of 15 December 1956 on the Equivalence of Periods of University Study, European Treaty Series - No. 21.

${ }^{10}$ UNESCO Convention of 21 December 1979 on the Recognition of Studies, Diplomas and Degrees concerning Higher Education in the States belonging to the Europe Region, UN Treaty Series No. 20966, adopted in Paris.

${ }^{11}$ For that purpose were developed a set of specific legal directives: Council Directives 77/452/EEC and $77 / 453 / \mathrm{EEC}$ of 27 June 1977 on recognition of qualifications of nurses; Council Directives 78/686/EEC and 78/687/EEC of 25 July 1978 on recognition of qualifications of dentistry; Council Directives 78/1026/EEC and 78/1027/EEC of 18 December 1978 on recognition of qualifications in veterinary medicine; Council Directives 80/154/EEC and 80/155/EEC of 21 January 1980 on recognition of qualifications in midwifery; Council Directive 85/384/EEC of 10 June 1985 on recognition of qualifications in architecture; Council Directive 85/432/EEC and 85/433/EEC of 16 September 1985 on recognition of qualifications in the field of pharmacy as well as Council Directive 93/16/EEC on recognition of qualifications in medicine.

${ }^{12}$ Council Directive 89/48/EEC of 21 December 1988 on a general system for the recognition of higher education diplomas awarded on completion of professional education and training of at least three years' duration, and its supplement Directives 92/51/EEC of 18 June of 1992 and 95/43/EC of 20 July 1995.

${ }^{13}$ See article 1 of Directive 89/48/EEC. 
of University Study ${ }^{14}$ was presented in 1990 aiding the recognition purpose, although maintaining the equivalence entitlement as instigated common standards.

\section{Scope of recognition}

On 11 April 1997 CoE/UNESCO Convention on the Recognition of Qualifications concerning Higher Education in the European Region (hereinafter, Lisbon Recognition Convention) ${ }^{15}$ replacing prior extant conventions. The Convention, Article I gives the following definition of recognition: "a formal statement by a competent recognition authority acknowledging the value of the qualification in question and indicating the consequences of this recognition for the holder of the qualification for which recognition is sought." These legal guidelines were implemented mainly through European Network of Information Centers network (henceforth, ENIC), created in 1994 by the CoE and UNESCO to develop policy and practice for the recognition of qualifications, in strict collaboration with NARIC Network.

The Lisbon Recognition Convention is, until nowadays, an international legal framework ratified by a total of 53 countries, almost all Member States of the Council of Europe, with the exception of Greece and Monaco, and eight more nonMember State countries beside the United States and Canada that signed but didn't ratify it. ${ }^{16}$ This legal document stipulates basic principles related to the assessment of qualifications; ${ }^{17}$ general requirements for access to higher education; ${ }^{18}$ basic principles for periods of study undertaken abroad ${ }^{19}$ and the fundamental standard that Parties should recognize higher education qualifications earned in the higher education system of any other Party unless a substantial difference can be shown, ${ }^{20}$ furthermore emphasizing the importance of both substantial and relevant differences.

In aiming to promote fair and transparent recognition procedures, this Convention acknowledges differences between higher education qualifications and states that these should be accepted unless a substantial difference can be shown which "...is straightforward..." However, given that "...no legal text can adequately outline what is meant by it, ',2 it is subject to different interpretations.

Furthermore, it's relevant to notice that the Convention Committee has approved subsidiary texts, namely (i) Recommendations on International Access Qualifications, $^{23}$ (ii) Recommendations on Criteria and Procedures for the Assessment of Foreign Qualifications, ${ }^{24}$ (iii) Recommendations on the Recognition

\footnotetext{
${ }^{14}$ Council of Europe Convention of 6 November 1990 on the General Equivalence of Periods of University Study, European Treaty Series - No. 138.

${ }^{15}$ Council of Europe/UNESCO Convention of 11 April 1997 on the Recognition of Qualifications concerning Higher Education in the European Region, European Treaty Series - No. 165.

16 "Chart of signatures and ratifications of Treaty 165", Council of Europe, accessed November 4, 2015, http://www.coe.int/pt/web/conventions/full-list/-/conventions/treaty/165/signatures?p auth=LBaAKApm.

${ }^{17}$ See Article III.1 of the Lisbon Recognition Convention.

${ }^{18}$ See Article IV.1 of the Lisbon Recognition Convention.

${ }^{19}$ See Article V.1 of the Lisbon Recognition Convention.

${ }^{20}$ See Article VI.1 of the Lisbon Recognition Convention.

${ }^{21}$ Sjur Bergan, "Academic recognition: status and challenges", in Assessment in Education: Principles, Policy \& Practice, 16:1, 2009, 47, DOI 10.1080/09695940802704070.

${ }^{22}$ Note 20.

${ }^{23}$ Council of Europe/UNESCO Recommendation on International Access Qualifications of 16 June 1999.

${ }^{24}$ Council of Europe/UNESCO Recommendation on Criteria and Procedures for the Assessment
} 
of Joint Degrees, ${ }^{25}$ and (iv) Recommendations the Code of Good Practice in the Provision of Transnational Education. ${ }^{26}$ These principles and recommendations are used for different purposes whether for further study - academic recognition - or work - professional recognition - because higher education qualification is also used to assess professional skills and competences. This clarification was implemented by the CoE in the Communication of 6 May 1996 on the synergies of academic and professional recognition" "because of the different legal bases and the specific objectives to be achieved, two complementary aspects of 'recognition' need to be taken into consideration." Thus, whereas academic recognition is regulated by international conventions, bilateral or multi-lateral agreements among States or Transnational education programs, implemented by ENIC-NARIC networks and decided upon in higher education institutions or national recognition bodies; the professional recognition is structured through national legislation, European Directives or international professional associations. Regulations are further assessed or decided by employers and professional or governmental bodies. ${ }^{28}$

However, as Bergan ${ }^{29}$ clarifies, in practice the distinction between academic or professional recognition is the purpose for which recognition is sought. Moreover, academic recognition is also divided in two sub-cases as cumulative academic recognition, for those applying to subsequent qualification, and academic recognition by substitution, to complete a part of an educational program in another State, "distinction that was not felt to be meaningful in practice and was never widely used." 30 Otherwise, professional recognition is distinguished between de jure professions, which are normally regulated by legal acts and specific organizations, while de facto professions aren't regulated and recognition is accomplished by employers.

Within this separation, the European Parliament and the CoE produced a specific Directive on the Recognition of Professional Qualifications (hereinafter, Directive 2005/36/EC). ${ }^{31}$ This directive is a polemical legal instrument that was amended several times until now and in 2010, still remained with its transposition incomplete in five Member States, ${ }^{32}$ according to the Scoreboard on the Professional Qualifications Directive. ${ }^{33}$ By means of this particular legal text, the system for recognition of professional experience was modernized in order to help "make labour markets more flexible, further liberalize the provision of services and promotes automatic recognition of professional qualifications." 34

of Foreign Qualifications of 6 June 2001.

${ }^{25}$ Council of Europe/UNESCO Recommendation on the Recognition of Joint Degrees of 9 June 2004.

${ }^{26}$ Council of Europe/UNESCO Code of Good Practice in the Provision of Transnational Education of 6 June 2001.

${ }^{27}$ Council Conclusions of 6 May 1996 on the synergies between academic recognition and professional recognition of qualifications in the Community, Official Journal of the European Communities 96/C 195/02.

${ }^{28}$ For further information see Rauhvargers, "Recognition of foreign qualifications".

${ }^{29}$ Bergan, "Academic recognition", 39.

${ }^{30}$ Bergan, "Academic recognition", 40.

${ }^{31}$ Directive 2005/36/EC of the European Parliament and of the Council of 7 September 2005 on the recognition of professional qualifications.

${ }^{32}$ Austria, Belgium, Greece, France and Luxemburg.

33 "Scoreboard on the Professional Qualifications Directive", Council of Europe, accessed November 4, 2015, http://ec.europa.eu/internal market/qualifications/docs/scoreboard 2010 en.pdf.

34 "Free movement of people - policy developments", European Comission, accessed November 
The scope of application of the Directive 2005/36/EC concerns only regulated professions qualifications, which implies that if a profession is not regulated in a Member State it is not necessary to submit the professionals' qualifications to a recognition process. Upon that purpose the Directive introduced a distinction, originated in the labour market that clarifies the dissimilarity between situations of occasional versus permanent professional service mobility.

Accordingly, temporary professional activity cases are beneath the European principle of the free to provision of services. Hence, "the rules that apply are more flexible...provided that you meet certain conditions. In most cases, you do not need to submit your qualifications for approval and you can practice your activity straight away. ${ }^{\prime 35}$ In this regard, this directive determines some common rules or procedures for the recognition of temporary mobility, just applied in cases where the professional physically moves to a host Member State, otherwise it's regulated by the directive on electronic commerce legislation ${ }^{36}$ or on services in the internal market. ${ }^{37}$

Herewith, it is underneath this Services Directive, which focuses on; "facilitating the exercise of the freedom of establishment for service providers and the free movement of services, while maintaining a bigh quality of services, "'s8 that other procedures for recognition and access to professional services activities were simplified. Considering the introductory notes on the Services Directive, which states "the elimination of barriers to the development of service activities between Member States is essential in order to strengthen the integration of the peoples of Europe and to promote balanced and sustainable economic and social progress," the aim of ensuring freedom of mobility and European citizenship within Member States becomes clear.

However, although ensuring citizenship rights, this services liberalization also brought the need to protect workers, introducing into the fray, the Court of Justice of the European Union (henceforth, CJEU). Analyzing the CJEU's jurisprudence on free movement of people and services since 2010, ${ }^{39}$ it can be submitted that there are several cases referring to fiscal legislation, taxation and social security for both, establishment and free movement of services, implying the present importance of ensuring the coherence of the tax regimes.

When the mobility is with a more permanent character, under the freedom of establishment, recognition gives the right to practice a specific professional activity, accessed through formal procedures that involve checking the professionals' qualifications. Within these distinctions, the European Parliament and the Council of Europe, through the Directive 2005/36/EC, generated three different systems for the recognition of professional qualifications:

- Automatic recognition for professional with harmonized training conditions (architects; dentists; doctors; midwives; nurses; pharmacists; veterinary surgeons);

4, 2015, http://ec.europa.eu/growth/single-market/services/free-movement-professionals/policy/ index en.htm.

35 "Users' Guide Directive 2005/36/EC", European Comission, accessed November 4, 2015, http://ec.europa.eu/internal_market/qualifications/docs/guide/users guide en.pdf.

${ }^{36}$ Directive 2000/31/EC of the European Parliament and of the Council of 8 June 2000 on certain legal aspects of information society services, in particular electronic commerce in the internal market.

${ }^{37}$ Directive 2006/123/EC of the European Parliament and of the Council of 12 December 2006 on services in the internal market.

${ }^{38}$ Article 1 of the Directive 2006/123/CE of 12 December, also known as "Services Directive" or "Bolskestein Directive".

${ }^{39}$ Digest of the case-law of ECJ on freedom of movement of people and services at http://curia. europa.eu/common/recdoc/repertoire jurisp/bull 4/tab index 4 04.htm. 
- A general system for other regulated professions;

- Recognition through professional experience.

In sum, the Directive 2005/36/EC concentrates the regulations on almost every situation of professional recognition with the exception of auditors; ${ }^{40}$ insurance intermediaries; ${ }^{41}$ lawyers ${ }^{42}$ or transport sector that have their appropriate European legislation. Also, this directive follows the implementation, in 2001, of the Recommendation on Criteria and Procedures for the Assessment of Foreign Qualifications (revised latter in 2010), which determines the norms and processes taken for the recognition of qualifications. Although it seems to be very easy to recognize professional qualifications under this Directive, it should be noted that every Member State is free to legally restrain, partial or fully, the access to particular profession inside the boundaries of the Internal Market rules.

More recently, in 2013, this Professional Qualifications Directive was modernized through its amendment by the adoption of Directive 2013/55/EU. Namely, this new Directive "introduces common training frameworks (CTFs) that will allow groups of Member States to agree curricula based on common sets of knowledge, skills and competences and other Member States may then opt in." ${ }^{\text {"43 }}$ It also introduces the European Professional Card, which is articulated with the Internal Market Information System, to simplify recognition for the purposes of strengthening the internal market and facilitate free movement of professionals. This card will be available to the public only in January 2016 for specific professions such as: nurses responsible for general care, pharmacists, physiotherapists, mountain guides and real estate agents.

\section{Enhancing recognition}

Within the succeeding years of the Lisbon Recognition Convention, the first steps were taken to the development of the so called European Higher Education Area (henceforth, EHEA) through the well-known Bologna Process, which was introduced by "the 1998 Sorbonne Declaration [that] set in motion the idea of the creation of a European area of higher education with a view to promoting mobility and employability." the Bologna process was prompted in inter-ministerial meetings and supported by the European Council of Lisbon (2000) and Barcelona (2002). It has 48 signatory countries which acquiesce that; "fair academic and professional recognition, including recognition of nonformal and informal learning, is at the core of the EHEA. ${ }^{\text {"5 }}$ Hence, it is clear that underneath this voluntary reform of higher education systems is the main axe of recognition of

\footnotetext{
${ }^{40}$ Directive 2006/43/EC of the European Parliament and of the Council of 17 May 2006 on statutory audits of annual accounts and consolidated accounts.

${ }^{41}$ Directive 2002/92/EC of the European Parliament and of the Council of 9 December 2002 on insurance mediation.

${ }^{42}$ Council Directive 77/249/EEC of 22 March 1977 to facilitate the effective exercise by lawyers of freedom to provide services and Directive 98/5/EC of the European Parliament and of the Council of 16 February 1998 to facilitate practice of the profession of lawyer on a permanent basis in a Member State other than that in which the qualification was obtained.

${ }^{43}$ Hana Horak, Nada Bodiroga-Vukobrat and Kosjenka Dumančić, "Professional qualification and diploma recognition in EU law", in InterEULawEast - Journal for International and European Law, Economics and Market Integrations, 1:1, 2014, 107.

${ }^{44}$ Anne West and Eleanor Barham, "Student mobility, qualifications and academic recognition in the EU", Assessment in Education: Principles, Policy \& Practice, 16:1, 2009, 27, DOI: 10.1080/09695940802704062.

${ }^{45}$ Bucharest Ministerial Communiqué of 27 of April 2012.
} 
qualifications with the purpose to promote mobility and facilitate access to the internal market.

In the context of the Bologna Process, many actions were taken to enhance comparability between the several national education systems, in which those instruments that improve recognition should be referred, such as the European Credit Transfer System or the European Qualification Framework. Furthermore, it was implemented a harmonized reform of degrees' systems, a common quality assurance and a transformation amongst the educational paradigm to a more student-centered approach, predicated upon learning outcomes. They aim to facilitate academic as well as professional recognition and the admission in the labour market.

Almost at the same time, another reform on educational systems of the European region was provided by the Copenhagen Process (2002), which aimed "to increase voluntary cooperation in vocational education and training, in order to promote mutual trust, transparency and recognition of competences and qualifications." ${ }^{\prime 46}$ Similar to the Bologna Process, this voluntary cooperation presented recognition instruments such as the European credit for vocational education and training and the portfolio's framework for transparency of qualifications and competences named Europass.

Lastly, it must be mentioned that some working groups on recognition are still improving these criteria and procedures, i.e. EHEA working group or the European Area of Recognition project, which assembled a Manual with practical guidelines for fair recognition of qualifications that "bas potential to genuinely become the EHEA standards and guidelines for recognition." ${ }^{\prime 77}$ Therefore, it could be assessed that in Europe, covering all its institutions and Member States, is emerging an active construction of legal procedures to enhance qualifications recognition, making its citizens able to freely move beyond State's borders to accomplish a professional activity.

\section{Evidences of recognition}

According to the Special Eurobarometer $417^{48}$ on European area of skills and qualifications report, the perceptions of European citizens about recognition of regulated professional qualifications can still constitute an obstacle to the fulfillment of this requisite for the free movement of professionals. In this report, findings were that only half of the respondents believed that their qualifications would be recognized in another Member State, as well as a similar proportion considers that studying and working abroad would not be recognized in their own country. These not so positive perceptions on the matter are fundamental because they, arguably, negatively affect decision of pursuing professional mobility within Europe.

Fortunately, these findings are not supported by the statistics on cases of recognition of professional qualifications. Hence, the overall statistics on establishment, from a period from 1997 to 2014, showed that there were $83 \%$ of positive decisions taken by the host countries and only $11 \%$ of neutral and $6 \%$ of negative decisions, which

\footnotetext{
${ }^{46}$ Declaration of the European Ministers of Vocational Education and Training, and the European Commission, convened in Copenhagen on 29 and 30 November 2002, on enhanced European cooperation in vocational education and training.

47 "Report by the EHEA Working Group on Recognition - 2012", EHEA working group on recognition, accessed November 6, 2015, http://www.ehea.info/Uploads/(1)/Recognition $\% 20$ WG\%20Report.pdf.

48 "Special Eurobarometer 417: European area of skills and qualifications", European Comission, accessed November 6, 2015, http://ec.europa.eu/public opinion/archives/ebs/ebs 417 en.pdf.
} 
comprises a total of 20639 negative decisions. ${ }^{49}$ In addition, in respect of temporary mobility, there were a total 689 negative decisions between 2007 and 2014. ${ }^{50}$

These statistics ground the context in which the prominence of the CJEU, in their promotion of a European citizenship based upon fundamental freedoms and rights, is unequivocal. Moreover, the role of the CJEU in the present configuration of the recognition systems of professional qualifications was, and is still, fundamental, since their extant corpus juris ${ }^{51}$ can be useful in aiding the evolution of the current European legal framework on recognition of professional qualifications.

Therefore, right before the Directive 2013/55/EU was adopted, amending the Directive on the recognition of professional qualifications (Directive 2005/36/EU), it was judicially solved by the CJEU in a case that involved a Greek professional with a German qualification and the Greek government because of a denied recognition. ${ }^{52}$ The CJEU ruled in favor of the partial recognition of the professional qualification and the stipulation of additional measures, ensuring that it was not; "intruding in national democracies but simply guaranteeing the rule of law in the Euro area. ${ }^{53}$ This ought to demonstrate that even if a European country like Greece, that didn't ratify the Lisbon Recognition Convention neither sign the Directive 2005/36/EC must adhere to Article 49 TFEU, which states; "within the framework of the provisions set out below, restrictions on the freedom of establishment of nationals of a Member State in the territory of another Member State shall be prohibited." In this regard; "the right to practice economic activities in another Member State is a fundamental right enshrined in the Treaty" ${ }^{\prime 54}$ that has to be ensured to every citizen of the European Union. Furthermore, refusing an academic recognition for the purposes of pursuing further studies, if not presented substantial differences, could interfere with the fundamental right to education, embodied in the European Charter of Fundamental Rights.

Likewise, more recently and under the current legal documents, cases such as Ordre des architects ${ }^{55}$ and Alain Brouillard ${ }^{56}$ address what nowadays is disputed in court. In both cases what is at stake is the ruling of the CJEU for the preclusion of the arguments that jeopardize the recognition of professional qualifications achieved in another Member state, so the workers can practice their profession in a host Member state.

Based on the above, one can argue that the current responsibility of the CJEU is to clarify limits where Member States and national institutions can deny access to the EU single market by refusing to recognize professional qualifications and, consequently, the European right of freedom of movement of professionals. In summary, this legal framework obeys a common denominator - the respect for the fundamental rights in

\footnotetext{
49 "Regulated Professions Database - Statistics on professionals moving abroad (establishment)", European Comission, accessed November 9, 2015, http://ec.europa.eu/internal market/ qualifications/regprof/index.cfm.

50 "Regulated Professions Database - Statistics on temporary mobility", European Comission, accessed November 9, 2015, http://ec.europa.eu/internal market/qualifications/regprof/index.cfm.

51 "List of judgments of the court of justice concerning professional recognition before the year 2010", European Commission, accessed November 9, 2015, http://ec.europa.eu/internal market/ qualifications/docs/judgments/list en.pdf.

${ }^{52}$ See ECJ decision on Nasiopoulos, Case C-575/11, dated June 27th 2013.

${ }^{53}$ Miguel Poiares Maduro, A New Governance for the European Union and the Euro: Democracy and Justice - in RSCAS Policy Papers 2012/11, Badia Fiesolana, European University Institute, 2012, 9.

54 "Users' Guide Directive 2005/36/EC", 6.

${ }^{55}$ See ECJ decision on Ordre des architects, Case C-365/13, April 30th 2014.

${ }^{56}$ See ECJ decision on Alain Brouillard, Case C-298/114, October 6th 2015.
} 
Europe. For this purpose Conventions, Directives, Recommendations, Declarations, or Judgments of the court, exist to guarantee that these fundamental rights are accomplished in every single Member State.

\section{Reflections upon recognition}

Within this perspective, it is also important to consider that transnational Directives "intended to provide a response to the "social vacuum" existent at the European level which comes from the fact that laws... are implemented at national level and many act at Community level'57 for professional purposes. This could be an indicator that the necessity of recognition of professional qualifications comes, in practice, from social and individual acknowledgment of the European citizenship.

Another common principle that guided the development of regulations on recognition was the economic integration for the competitiveness of Europe. At assorted sides of the "balcony" of scientific observation - law, education, politics and sociology - is the common school of thought that the economic reasoning nowadays prevails. Besides, "as reflected in the Europe 2020 strategy, education has become a priority in European policies. Education and training systems need to offer solutions to the key challenges that Europe is facing. "58 Furthermore, according to the human capital theory; "...the value of competences expires with time. ${ }^{59}$ This exemplifies the importance of lifelong learning, and thus, the continuous recognition of qualifications, within the European project.

Thus, as asserted by Offe; "the EU has served so far, apart from being a machinery of economic liberalization, as a monitoring and regulatory device through which major deviations from standards of buman rights and liberal democracy can be kept under control." ${ }^{100}$ Indeed, it was noted that the liberalization of services was essential to ensure free movement of services, enhancing the internal market and simplifying the recognition procedures of professionals working in service activities between Member States.

However, recognizing for the sole purpose of improving the internal labour market, seeing professionals as human capital and qualifications or competencies as raw material for employability within the market amends the education main purpose of access to citizenship and active democratic participation with economic objectives.

Furthermore, the cited deviations could be debated, for instance, in line with the tendency for the harmonization of unlike sociocultural systems, which would destroy one of the biggest European value - its diversity. Truly, with so many political and legal transformations, "it seems to be of major importance to question if the transnational change implicated by the Bologna Process brought more homogeneity or, on the contrary, reinforce the existing heterogeneity. " Indeed, does the implementation of harmonization procedures and common standards Europe-wide really respect and accept differences? Although

\footnotetext{
${ }^{57}$ Bruno Mestre, "A descentralização da negociação coletiva - perspetivas de Direito Comunitário e Comparado à luz da teoria das Institutional Complementarities", in Direito do trabalho + crise = crise do direito do trabalho?, Catarina Carvalho e Júlio Gomes (Coord.), Coimbra: Coimbra Editora, 2011, 116.

${ }^{58}$ Jonatan C. Muñoz, Christine Redecker, Riina Vuorikari and Yves Punie, "Open Education 2030: planning the future of adult learning in Europe", Open Learning, 28:3, 2013, 171, DOI: 10.1080/02680513.2013.871199.

${ }^{59}$ Muñoz et al., “Open Learning 2030”, 171.

${ }^{60}$ Claus Offe, "Europe Entrapped: Does the EU have the political capacity to overcome its current crisis?” European Law Journal, 19:5, 2013, 596, DOI 10.1111/eulj.12071.

${ }^{61}$ Manuel Torres and Carlinda Leite, "Assessment Of and For Learning in Higher Education", Transnational Curriculum Inquiry, 1, 2014, 26.
} 
this discussion is still a fiery debate, it is clear that in the matter of recognition of professional qualifications, the first legal European documents presented the idea of complete equivalence, which attempted to homogenize qualifications, but latter on the notion prompted by the European institutions, mainly since the Lisbon Recognition Convention, was that of acceptance and recognition between qualifications of different Member States, ensuring the control of these deviations whilst respecting and including European cultural diversity.

Therefore, within the European project recognition must really recognize diversity and cooperate with it, through mutual gains, as Cunha Rodrigues explained, "the multiculturalism reflected in the changes introduced by the Lisbon Treaty suggests a new field of observation obedient to the accommodation and harmonization of principles and attentive to the ideas of difference, tolerance, acceptance and trust.' 62 So, it can be concluded, that although "European Union law deeply transforms the national law of the Member States," ${ }^{13}$ this transformation is under the basic assumption that cooperation and integration in the European space could be translated on the motto "united in diversity".

Thus, it should be noticed that "the distinctiveness of cultural legacies and identities of European nations can be preserved and protected against homogenizing market forces only through the belp of supranational agency. In view of these precious capacities of the EU of being a catalyst of supervisory control and cooperation," ${ }^{4} 4$ implementing this supervisory control and cooperation should follow a process of democratization because it "...is the protection of diversity. The story of contemporary Europe is unique in the complementary and parallel strengthening of national identities together with the respect for the spirit and values of Europe. ${ }^{95}$

This miscellaneous citizenship, between national and European standards if democratized, has the potential to "empower ...citizens at a global level, regulates and arbitrates externalities between states, and protects social justice both by reforming the Member States and supplementing them. ${ }^{.66}$ Hence, it must be understood that recognition of professional qualifications should follow the established European legal framework, constructed to ensure the European citizens rights'.

By the information discussed in this paper, it seems that the recognition of qualifications is proceeding accordingly with these principles and values, constituting a great mechanism for inter-change between States, enterprises and professionals, acknowledging and cooperating within the cultural differences. Indeed, it can be said that democratization of Europe through the fair recognition of qualifications today provides conditions and support to fulfill the European freedoms on professional mobility, enhancing the EU single market and European citizenship.

\footnotetext{
${ }^{62}$ José N. Cunha Rodrigues, "Acknowledgment of the Honoured”, UNIO-EU Law Journal, 0, 2014, 5.

${ }^{63}$ Klaus Günther, "Legal Pluralism or Uniform Concept of Law? Globalisation as a problem of legal theory", in No Foundations: Journal of Extreme Legal Positivism, 5, 2008, 5.

${ }^{64}$ Offe, "Europe Entrapped", 596-597.

${ }^{65}$ Iveta Radicova, "Shock to the System: Division, Unemployment and the Common Sense of European Institutions”, Journal of Common Market Studies, 51 ,2013, 62, DOI 10.1111/jcms.12048.

${ }^{66}$ Maduro, "New Governance for the EU", 21.
} 